\title{
The United Nations and the Politics of Selective Humanitarian Intervention
}

\author{
POR Tatiana Matias* \\ * International Relations and Diplomacy, Shanghai University, China
}

Binder, M. (2017).

The United Nations and the Politics of Selective Humanitarian Intervention. Cham: Palgrave Macmillan

The concept "responsibility to protect" was born after the Rwandan genocide when, at the time, Secretary-General Kofi Annan claimed a "responsibility to protect" civilians from genocide, ethnic cleansing, and crimes against humanity (Annan, 2002). Responsibility to Protect gives the UN the responsibility to intervene in another State to protect civilians from suffering. While many states agree with this legal principle, others continue to criticize it (Damboeck, 2012, 288). With the increase of the Security Council's humanitarian interventions since the end of the Cold War, a significant shift in international politics took place. Nonetheless, the Security Council does not address all humanitarian crises, and they have remained highly selective. The UN Security Council's selective response to the humanitarian crisis has become one of the most debated issues in international affairs. This selective action is well explained in the book: The United Nations and the Politics of Selective Humanitarian Intervention, by Martin Binder.

Throughout the book, Binder's main argument is that a single factor cannot explain the Council's respond but is driven by the "interplay of humanitarian considerations, material interests, and institutional effects," more specifically: (1) "the extent of human suffering in the crisis," (2) "the extent to which a crisis spills over to neighboring countries and regions," (3) "the ability of a target state to resist outside intervention (countervailing power)," (4) "the extent of material and reputational resources the UN's has committed to the resolution of a crisis in the past (sunk costs)" (p. 3) and finally, he also considers but not so decisively, (5) "the level of international media attention for a crisis" (p. 18). Binder believes that these factors together offer a great explanation that covers more than 80 percent of the Council's response to humanitarian emergencies after the Cold War. Likewise, he considers that "specific interests of 
individual powerful members - while important in shaping Security Council action - are not sufficient to explain collective (non-) intervention decisions of the Council" (p. 251).

During the Cold War, the author states that a lot of the resolutions were blocked due to the rivalry between the two veto powers: the United States and the Soviet Union. After the Cold War the situation changed, and the Council approved many resolutions. Furthermore, the definition of what constitutes a threat to international peace and security was widened. While before was only referred to conflicts between States, the concept started to include situations within states, including civil wars, humanitarian crises, and coups against democratically elected governments. However, council members continue to disagree over the responses to humanitarian crises. In the Syria case, for example, China and Russia have used their veto to stop Council action that goes against their interests.

Binder adopts a broad concept of humanitarian intervention. In addition to the use of military force, this concept also includes economic sanctions, peacekeeping, and humanitarian assistance. He explains that the Council can take a strong action (coercive measures under Chapter VII of the UN Charter) if the extent of a humanitarian crisis is large, if the Council has been involved in that crisis and has committed material and reputational resources to its resolution. He defends, however, that this leads to intervention only when the crisis also generates substantial negative spillover effects or when the target state is militarily weak and thus unable to create strong countervailing power against outside interference.

In Bosnia, the Council took intense action and ultimately authorized the use of military force. In Darfur, however, UN involvement was initially very weak, it eventually grew to a peacekeeping mission (UNAMID), but intervention never reached the level of that in the case of Bosnia. Also, to prove his argument he uses other examples of Council's "mixed response" to crisis such Côte d'Ivoire, Libya, and Syria. His objective is to study the humanitarian emergencies that Security Council intervened and the ones that remained not covered by the Council, although he admits that his theory is not applicable for all crises.

In the second chapter, Binder takes into consideration how decisions are made in the Security Council to prove that due to institutional dynamics and the voting rules, "collective intervention decisions by the Council are different from unilateral ones" and they require different analyses and explanations. In this chapter, he also presents the motivational aspects of the Council's actions.

In the third chapter, the author shows that a combination of four variables that result in selective UN intervention. The human suffering and considerable involvement in a crisis by international institutions are the key factors for strong Security Council action, but they must be combined with limited countervailing power of the target state or with negative spillover effects to neighboring countries. The limited Council action is explained by the strong countervailing power of the target state if other conditions are fulfilled. 
In the fourth chapter, Binder offers the study of the motivations that led to an authorization for the use of military force in Bosnia. He concludes that, and in accordance to his argument, a combination of four reasons was on the base of this decision: first, the humanitarian concerns for the Bosnian population, and the moral pressure by human rights organizations and the media; second, the possibility of conflict spreading to Western Europe (refugees flows) and the destabilization of the Balkans; third, the Security Council engaged a lot of investment to resolve the conflict, and when hundreds of UN blue helmets were made hostage by the Bosnian Serbs, the mission was about to fail. To avoid the loss of the investment already done, the Council authorized the use of military force to end the war, and fourth, the incapacity of the Bosnian Serbs and the Serbian government to countervail against the intervention of UN and NATO.

In the fifth chapter, Binder examines the Council's reaction in the case of the Darfur crisis, which was very restricted at the beginning. Once more, a combination of four motivational aspects influenced the response in this case. For an extended period, Sudan's government, with supporters in the Council (China and Russia) resisted against a UN intervention. Second, the UN was not involved in the crisis before, like in the case of Bosnia. Another motive was the fact that the Security Council's involvement could spread the conflict outside Darfur's borders. When the conflict started to grow to Chad and the magnitude of the crisis was revealed, the Security Council imposed intense action to end the conflict.

In the sixth chapter, Binder tries to reinforce his argument, the Council's response to the recent crises in Côte d'Ivoire, Libya and Syria can only be explained by a mixture of motivational dynamics. In Côte d'Ivoire case, the decision to send a military operation in the post-election crisis was motivated by a combination of humanitarian problems and the necessity to avoid the crisis to developing to other West African countries, mainly to Liberia. Furthermore, the UN wanted to protect its previous commitments in the country (peacekeeping and peacebuilding missions), and President Gbagbo's armed forces were incapable of resisting the UN's and France's interventions. In the case of Syria, the conflict is still taking place, and it has destabilized neighboring countries with millions of Syrian refugees, with negative effects on the Middle East region and with tremendous human suffering. Yet, the Security Council's limited response is the result of the strong countervailing power of the Assad government and the support of two veto powers, Russia and China, who have resisted all Council's efforts to take coercive measure against the Syrian regime. Even though he considers that the Côte d'Ivoire and the Syria cases go according his argument, the Libyan situation was an exception since only three of the main four motivations took place. The use of force in Libya resulted from humanitarian concerns and to prevent crisis spillover, in particularly the flow of refugees that would cross the Mediterranean to get to the European countries. It was also driven by the lack of military capabilities from Gaddafi regime and the absence of allies to block Council's decision of military 
intervention. Nonetheless, the Council's choice was unexpected and was not motivated by an institutional dynamic of path dependence.

Finally, in the seventh chapter, Binder reviews the central aspects of his research and debates their theoretic and normative effects. As Binder points out, it is essential to notice the current discussion around the Council's uneven behavior on the crisis in Libya and Syria, although these are merely two specific cases. The Council members only agreed to take active measures in response to situations of large-scale human suffering on 13 out of the 31 major humanitarian crises considered in his study. However, looking at the Security Council during the Cold War, Binder believes that significant progress has been made.

The lack of legitimacy by the Security Council, "not only damages the credibility of humanitarian intervention but also the legitimacy of the Council, if not the legitimacy of the international order more generally" (p. 254). It is also essential to notice, and which was demonstrated with the specific cases of the book, frequently, private interests of international corporations are behind the States' behavior and can influence the power of governments. These conclusions endure the world debate of the Security Council's selective response to humanitarian crisis, which an answer has not been found. One thing is for sure: foreign policy positions of individual Security Council members should never result in collective Council policies. Accordingly, finding new solutions to prevent national or/and companies' private interests to control UN Security Council decisions is crucial. If the Security Council loses its legitimacy, it will undoubtedly affect the multilateral world where we are living today. On a negative note, Binder fails to propose a solution to this matter.

Nevertheless, Binder's book is indispensable reading for the study of international intervention. His findings contribute to a better understanding of the way international organizations work and how they make decisions, which is relevant since international organizations are increasing their power in world politics. Notably, the UN Security Council is still considered, by some scholars, "the most powerful international institution in the history of the nation-state system" (Cronin and Hurd, 2008, cited in p. 4). The selective intervention by UN Security seems to be a debate to continue.

\section{References}

Annan, K. (2002), Secretary-General of the United Nations Addresses International Peace Academy Seminar on "The Responsibility to Protect." Retrieved from <https://www. un.org/press/en/2002/sgsm8125.doc.htm>.

Damboeck, J. (2012). Humanitarian interventions: western imperialism or a responsibility to protect? An analysis of the humanitarian interventions in Darfur. Multicultural Education \&Technology Journal, 6(4), 287-300. doi:10.1108/17504971211279536

Hurd, I. (2017). The United Nations and the Politics of Selective Humanitarian Intervention. Cham: Palgrave Macmillan. 
Jones, J. (2015). Humanitarian Intervention in a Multipolar World. Washington University Global Studies Law Review, 15(1), 161-190. Retrieved from <http://openscholarship. wustl.edu/law_globalstudies/vol15/iss1/9>. 
